Tér és Társadalom 23. évf. 2009/1. 219-226. p.

Tér és Társadalom

XXIII. évf. 2009 1: 219-238

\title{
KÖNYVJELZÖ
}

\section{HORVÁTH GYULA (SZERK.): REGIONÁLIS FEJLŐDÉS ÉS POLITIKA AZ ÁTALAKULÓ OROSZORSZÁGBAN}

(MTA Regionális Kutatások Központja, Pécs, 2008. 471 o.)

\section{GYURIS FERENC}

Míg a szocializmus idején nálunk is sok munka taglalta a Szovjetunió gazdaságföldrajzát, az elmúlt másfél évtizedben nagyfokú érdektelenség mutatkozik Földünk legnagyobb területú államának területi kérdéseivel szemben, annak közelsége és gazdasági, politikai erősödése ellenére. Ezt az indokolatlan közönyt töri meg a Régiók Európája sorozat harmadik kötete, melyben a témát „testközelböl” ismerő orosz kutatók, egyetemi tanárok járják körül Oroszország területi fejlödésének és az ezekhez kötődő regionális tervezésnek a legfóbb kérdéseit.

Az Oroszországi Tudományos Akadémia alelnökének rövid köszöntője után, melynek hangsúlyos gondolata a területi kutatások kiemelt gyakorlati jelentôsége egy ilyen nagy kiterjedésủ és erősen tagolt államban, a kiadvány szerkesztője, Horváth Gyula tollából olvashatunk frappáns áttekintést Oroszország regionális folyamatainak, illetve területi politikájának változásairól, régi és új kihívásairól. A rendszerváltás utáni makrogazdasági helyzetkép felvázolását követően részletes elemzés tárgyát képezi, milyen intézkedések és hogyan befolyásolták az ország területi folyamatait a szovjethatalom évtizedeiben. Ezt követi a rendszerváltás utáni Orosz Föderáció területi vonatkozásainak bemutatása, fỏként a regionális fejlettségi és társadalmi, demográfiai egyenlötlenségekre, az orosz településrendszer aránytalanságaira, valamint a jelenlegi területi politika hiányosságaira és az új területfejlesztési stratégia fontosságára összpontosítva.

A bevezetőt az orosz kutatók tanulmányai követik, négy tematikus fejezetbe rendezve: „A Szovjetunió széthullása és az új integráció esélyei”, „Térbeli társadalmi és gazdasági folyamatok", ,A területi tervezéstől a regionális politikáig”, valamint „Városi és rurális Oroszország”.

Miként címe is sugallja, az első rész még nem az Orosz Föderáción belüli folyamatokat, hanem ezek tágabb kontextusát elemzi, Oroszország nemzetközi súlyára, a volt Szovjetunió utódállamai közti együttmúködési lehetőségekre összpontosítva. A blokk első Szerzője, Andrej Trejvis írásából kitünik, milyen fontos szerepet kap a méret kérdése az orosz politikai, tudományos és közgondolkodásban. Ebből kiindulva matematikai-statisztikai változók és kartogram-térképek alkalmazásával tekinti át Oroszor- 
szág és a Szovjetunió más nagyhatalmakhoz viszonyított méretének 20. századi változásait - a méret fogalmába a területet, a népességszámot és a gazdasági teljesítményt is beleértve. A tanulmány utolsó részében pedig egymásra illesztett topologikus térképek segítségével kerül sor Oroszország és az orosz régiók - különböző szempontok szerinti - nagyságának más országok nagyságával való összevetésére.

A volt szovjet tagköztársaságok közötti integrációs lehetőségeket Leonyid Vardomszkij tekinti át két, geopolitikai szemléletü tanulmányában. Első írásában lényegre törően vázolja a Szovjetunió szétesésének, illetve a térség későbbi gazdasági, politikai széttagolódásának hajtóeröit és következményeit. Részint itt, részint a második írásban kerül sor a FÁK jellemzőinek bemutatására. A Szerzó nem kerüli meg a „kínos kérdéseket” sem, melyeket többnyire hüvős tárgyilagossággal taglal: bemutatja, miként tekintette Moszkva a szerveződést az orosz világhatalmi pozíció visszaállítását elösegítő eszköznek („Nagy Testvér-szindróma”), majd hogyan térítette el saját érdekeinek kemény képviselete az integráció mélyítésének szándékától. Említést nyer az is, hogy a FÁK éppen súlytalanságának és ezzel összefüggő csekély fenntartási költségeinek köszönhette fennmaradását egy rendkívül sokszínü országcsoporton belül. A Szerzó második írásának különleges értéke az egyes utódállamok közötti, a FÁK-tól fưggetlen, hazánkban alig ismert nemzetközi szervezödések (az Eurázsiai Gazdasági Közösség, az Orosz-Fehérorosz Államszövetség, illetve a GUAM) fejlődésének, jellemzőinek részletes ismertetése.

A kötet második fejezetében már az Oroszországon belüli regionális folyamatok kerülnek előtérbe. Ennek elsó tanulmányában Andrej Trejvis elemzi a fơderáció fejlődésének természet- és társadalom-fơldrajzi korlátait. A Szerző áttekinti, egyben értékeli a Szovjetunió és Oroszország fekvésének fỏbb közös vonásait, hangsúlyosan a meleg tengerekre való kijutás korlátozott lehetőségeit, valamint a sokszomszédúságot. Utóbbihoz kapcsolódóan térképen tünteti fel az orosz határvidékek „geopolitikai zónáit, csomópontjait és körzeteit"; tanulságos volna ezek lehatárolási szempontjainak taglalása is, amire azonban sajnos nem kerül sor. Nagyon érzékletes az Oroszország és a többi szovjet utódállam közötti - utóbbiakat hátrányosan érintő - egyirányú kereskedelmi függés bemutatása. A Szerző részletesen taglalja a szélsőséges éghajlatnak és a roppant kiterjedésnek az északi és keleti országrészek benépesítésére, gazdasági kiaknázására, valamint az országon belüli közlekedésre gyakorolt erőteljes akadályozó hatásait. Ehhez kötődően több „geodeterministának" nevezett szakértői álláspontot ismertet - komoly kritikai éllel -, amely az extrém természeti adottságokban látja Oroszország fejlődésének alapvető gátját. A hasonló szélsőséges vélemények bemutatása mindenképpen nagy érdeme a tanulmánynak, hisz érdekes mozaikokat tár fel egy fontos probléma tudományos recepciójából.

A következỏ tanulmányban Natalja Zubarevics járja körül a nagy és növekvó területi egyenlötlenségek kérdését, meglehetỏsen sok szempontból. Munkájában részletes elemzés tárgyát képezik a gazdasági (egy fơre jutó GDP, ipari termelés, beruházási volumen), valamint a demográfiai (népszaporulat, születéskor várható élettartam, képzettségi) különbségek, ezek okai, következményei és kölcsönhatásai. A területi vonatkozásokat a színvonalas ábrákkal kiváló összhangban lévő szöveges 
Tér és Társadalom 23. évf. 2009/1. 219-238. p.

elemzések taglalják, sokszor egészen döbbenetes tényekre világítva fényt (ilyen pl., hogy a Tuva Köztársaságban ,a születéskor várható élettartam - a kiterjedt alkoholizmus miatt - nem haladja meg a 46-50 évet" [161. o.]). A Szerző az írás végén lehatárolja a legdinamikusabb övezeteket, és elemzi jövőbeli fejlődési kilátásaikat.

A második fejezet fontos részét képezi Andrej Trejvis újabb tanulmánya, melyben Oroszország foglalkozási és termelési szerkezetének időbeli változásait mutatja be. A kelet-közép-európai országok szempontjából is megfontolandó tanulságos észrevételeken túl az írás rendkívüli értékét három mintakörzet (a moszkvai, az ivanovói és a permi) időbeli - fóként 1991 utáni - fejlödésének bemutatása képezi. Igaz, a mintatérségek kiválasztása kissé esetleges, ám ez semmit nem von le a terepi bejárás megfigyelésein alapuló, az „orosz valóság” fonákságait felvillantó, roppant plasztikus helyzetelemzések értékéből.

A következő tanulmányban Olga Kuznyecova az Oroszországban jelen lévő nagyvállalatok termelésének területi vonatkozásait tekinti át. A cégek ágazati megoszlása, tevékenységüknek a regionális fejlődésre gyakorolt hatása után az egyes ágazatok termelésének, valamint jövőbeli fejlesztési potenciáljának területi vonatkozásairól olvashatunk. Az igen alapos elemzés fontos összefüggésekre irányítja rá a figyelmet; külön értéke emellett, hogy számos konkrét beruházási tervröl szolgál információval.

A mezőgazdaság területi szerkezete áll Tatyjana Nefjodova munkájának középpontjában. A tanulmány az orosz agrártermelés területi egyenlőtlenségeinek részletes bemutatásával indul, egyaránt ismertetve a diszparitások makroszintủ és városvidék-léptékü vonatkozásait. Ezt követően igen alapos elemzést olvashatunk az 1990 utáni gazdasági átrendeződésnek az agrártermelés kibocsátására, valamint a szektor szerkezetére és területi elrendeződésére gyakorolt hatásairól. A sok ábrával illusztrált, rendkívül informatív írást az állami agrárpolitika bemutatása képezi, melyben a Szerzö elsösorban a hiányosságokra (,Oroszország óriási sokféleségének a mellôzzése" a tervezésben), illetve a jövőbeli kihívásokra (a mezőgazdasági vállalatok gyenge horizontális kooperációjának elmélyítése) mutat rá.

A kötet második részében olvasható Szergej Tarhov közlekedés-földrajzi tanulmánya is. Ebben az orosz közlekedési rendszer jellemzőinek általános áttekintése mellett az egyes szállítási módok bemutatása, egy külön fejezetben pedig az 1990 utáni változások ismertetése szerepel. Bár a nagy mennyiségü és naprakész statisztikai adat jól érzékelteti az országos tendenciákat, a Szerző elemzése alapvetően leíró jellegủ, az indokoltnál talán erősebb müszaki szemléletet tükröz.

A könyv e részét Irina Volkova, Genrietta Privalovszkaja és Tamara Litvinyenko írása zárja, mely a természeti erőforrások felhasználásának gazdasági, társadalmi vonatkozásait tárja fel - tárgyilagosan, de sok esetben kritikai hangvétellel. A Szerzök rámutatnak, hogy Oroszország erőforrásbőségének, a tetemes nyersanyagexportnak nemcsak pozitív, hanem negatív hatásai is vannak (pl. az állami költségvetés erösödö függése e termékek világpiaci árától), melyekre hosszú távon kizárólag a gazdasági szerkezet diverzifikálása, a szociális infrastruktúra fejlesztése jelenthet hatékony ellenszert (erre pozitív példaként említenek egyes nyugat-szibériai körzeteket). Különösen értékes a tanulmánynak az a része, amely a nyersanyagok kiterme- 
Tér és Társadalom 23. évf. 2009/1. 219-238. p.

léséböl származó adóbevételek egyes területi szintek közötti megoszlását értékeli. Érzékletes elemzést olvashatunk arról, hogy a befizetések döntỏ részét - az utóbbi évek centralizációs folyamatainak köszönhetően - az állam fölözi le, miáltal a nyersanyagágazatból származó adóbevételek csak a monostrukturális bányászati körzetekben gyakorolnak érdemi hatást a helyi gazdaság fejlődésére. Mindezen túl szó esik a nyersanyagrégiók fejlödésének távlati problémáiról, a készletek kimerülését követő időszak kihívásairól és lehetőségeiröl.

A kötet harmadik nagy fejezete a területi tervezés és a regionális politika problémakörét járja körül. Ennek nyitó tanulmányában Andrej Trejvis elsöként a centralista és a regionalista tendenciák időbeli váltakozásának okait és következményeit tekinti át a cári Oroszországtól kezdve a Szovjetunión keresztül napjaink orosz államáig. A Szerzö kísérletet tesz az egyes országrészek elszakadási veszélyének meghatározására; kár, hogy a látványos térképeken is ábrázolt eredmények számítási módszertanát érdemben nem ismerteti. Végezetül megvizsgálja, milyen tényezők hatnak napjainkban a centralizáció, illetve a regionalizmus irányába, miközben egyértelmủen állást foglal bármelyik tendencia szélsőséges értelmezése ellenében.

Szergej Artobolevszkij igen alapos, kritikai szellemiségủ írásában az orosz regionális politika 1990 utáni fejlődéstörténetét ismerteti. Felhívja a figyelmet a rendszer komoly hiányosságaira ( $\mathrm{pl}$. a területfejlesztési törvény hiányára), illetve a meglévő eredmények zömének látszólagosságára (pl. hogy a 2004-ben létrehozott Regionális Politikai Minisztérium a gazdasági hatékonyság növelésére koncentrál, nem a terïleti kiegyenlítés elősegítésére). Ezen kívül tételesen sorra veszi a hatékony területi politika kialakításának akadályait, az intézményi és jogi hiányosságoktól kezdve a forráshiányon keresztül a monitoring és a tudományos bázis gyengeségéig. Végezetül rámutat arra, hogy Oroszország sokat profitálhat a külföldi tapasztalatok megismeréséböl, ám a tervdokumentumokban gyakorta emlegetett, hangzatos területfejlesztési eszközök (pl. a klaszterek vagy a „növekedési központok”) alkalmazása csak az orosz reálfolyamatok figyelembevételével hozhat érdemi eredményeket.

Ennél is kritikusabb hangot üt meg tanulmányában Vjacseszlav Szelivjorsztov, aki az orosz regionális fejlődés és területpolitika „mítoszaival” igyekszik leszámolni. Keményen bírálja azt a felfogást, amely Oroszországban a regionális politikát másodlagosnak tekinti az általános gazdasági növekedéshez képest. Emellett nagyon határozottan mutat rá a „divatos” teruletfejlesztési koncepciók hiányosságaira (kiemelve például, hogy a polarizált fejlesztéspolitika által kedvezményezett nagyvárosi agglomerációk zöme képtelen „kisugárzó gócként” müködni), számos leegyszerúsítő modell (pl. a Zipf-törvény) alkalmazásának korlátaira, valamint a regionális problémák megoldását célzó technokrata koncepciók irrealitására (melyek szerint például az orosz Észak ,, lakosságát pedig át kell telepiteni” [319, o.]). Elutasítja továbbá azokat a véleményeket, amelyek az Uralon túli területeket óriási gazdasági tehertételnek nevezik, és azokat lehetöség szerint „természeti tartalékterületté” alakítanák; ehelyett nevezett térségek komplex, a nemzetgazdaság teljesítőképességéhez igazodó fejlesztésének lehetséges irányait taglalja. 
Tér és Társadalom 23. évf. 2009/1. 219-238. p.

A Szerző az irányú véleményét is kifejti, hogy a szovjet időszak területfejlesztési munkảjảnak számos értékes - megtartásra érdemes - hozadéka volt, bár érzésünk szerint az elhibázott jelen és a megbecsülést érdemlö múlt ellentétpárjának megalkotásakor komoly túlzásokba esik (pl. mikor azt állítja, a mai regionális stratégiák „aligha vehetik fel a versenyt a régebbi, megalapozott és tudományosan kidolgozott" stratégiai dokumentumokkal [324. o.]). A tanulmány végén a szibériai „,kínai veszedelemröl", ennek erőteljes túlbecsléséröl olvashatunk.

Igor Pilipenko írásának középpontjában a klaszterek állnak. Az elemzés a versenyképesség és a klaszterek fogalmának elemző bemutatásával kezdődik, ismertetve a klaszterpolitika történelmi előzményeit és típusait. Ezt követően a klasztereket és a szovjet területi-termelési komlexumokat hasonlítja össze a Szerző, tételesen feltárva a két kategória közötti fô különbségeket. Végezetül a klaszterpolitika oroszországi alkalmazásának lehetőségeit elemzi, világosan bemutatva ennek területi szintenként eltérő feltételeit, az orosz klaszterek kialakulási feltételeinek hiányosságait, de ismertetve néhány pozitiv példát is.

A következő tanulmányban Vjacseszlav Szelivjorsztov ad időbeli áttekintést a szibériai régiók fejlesztését célzó kezdeményezésekről. Az első rész a kapcsolódó intézmények (főként a Szovjet Tudományos Akadémia Szibériai Tagozatának) eredményeit és időbeli változásait ismerteti. Ezután a Szibéria kérdésével foglalkozó tudományos konferenciák és expedíciók történetét elemzi, rảmutatva, hogy a politikai, a gazdasági és a kutatói szféra részvételével zajló rendezvények 1991 előtt komoly ráhatással voltak a területi vonatkozású politikai döntésekre, azóta viszont a tudományos háttér és a politikai közötti ilyetén kapcsolat - utóbbi érdektelensége miatt - hiányzik. Említést nyer az is, hogy míg az 1990 elötti, mereven ágazati szemléletü tervdokumentumok nem foglalkoztak Szibériával, mint földrajzi egységgel, addig újabban - paradox módon - a prosperáló nyugat-szibériai régiók a központi tervezés drámai hanyatlásával párhuzamosan mélyítik el saját tervezỏ munkájukat. Mindezzel együtt a Szerző szükségesnek tartja a szibériai régió egészére vonatkozó tervdokumentumok elkészitését, melyek közül a már elkészült „Szibéria” szövetségi célprogramot sikertelensége ellenére iránymutató kezdeményezésnek minősíti.

Jevgenyij Lejzerovics írásában a gazdasági mikrokörzetekkel foglalkozik, melyeket az emberföldrajz kultúrtájához hasonló, komplex, de kimondottan gazdasági vonatkozású egységként, ,az orosz valóság területi szintjeként” (359. o.) értelmez. Az elméleti bevezetôt követően a 463 orosz gazdasági mikrokörzetet hét csoportba sorolja, melyeket innovációs helyzetük, szomszédsági viszonyaik és közlekedési állapotuk alapján értékel. Felhívja a figyelmet arra, hogy a különböző kategóriák eltérő területfejlesztési beavatkozásokat igényelnek, miáltal - véleménye szerint - a regionális politikának is a mikrokörzetekre kellene koncentrálnia, amit viszont nehezít, hogy azok zöme nem esik egybe a közigazgatási egységekkel.

A harmadik rész zárótanulmányában Olga Kuznyecova a központi és a regionális költségvetések közötti transzfereket, a regionális költségvetések adó- és transzferbevételeit, valamint -kiadásait elemzi. Írása rávilágít az állami szint erőteljes dominanciájára, az orosz költségvetési rendszer komoly bizonytalanságaira, az egyes 
területi szintek hatáskörének átfedéseire. Különösen érzékletes az adóbevételek nem megfelelő területi elosztásából fakadó gondok leírása. Ilyen probléma jelentkezik az agglomerációkban, ahol a személyi jövedelemadó munkahely szerinti befizetése miatt az elövárosok forráshiánnyal küszködnek (éppen ellentétes problémát generálva, mint a nyugat-európai országokban); a de facto a regionális és a helyi szint által finanszírozott oktatásban, melynek minőségét és hosszú távú gazdaságélénkítő hatásait éppen a térség gazdasági fejlettsége határozza meg; valamint az állami költségvetés regionális támogatási alapjánál, mely a forrásokat túl sok térség között forgácsolja szét, miközben nem ösztönöz kellően a felzárkózásra.

A kötet utolsó fejezete Oroszország városi és rurális térségeinek viszonyait taglalja. Az elsỏ tanulmány Szerzői, Grigorij Lappo, Pavel Poljan és Tatyjana Szelivanova tömör írásukban a városi agglomerációk időbeli fejlödését tekintik át, rövid történeti kitekintéssel, de elsősorban az elmúlt szük két évtized folyamataira koncentrálva. A tanulmány érzékletesen mutatja be, hogyan követte a szovjet időszak urbanizációját 1991 után a falvakból a városokba irányuló migráció visszaesése, valamint számos város faluvá történő visszaminősülése (melyet szegényebb városok kezdeményeztek a vidéki térségeknek juttatott támogatások rendszerváltozás utáni jelentős emelkedése miatt). Rendkívül érdekes az egykori zárt városok fejlődését ismertető rész, melynek "még továbbra is maradtak különleges térségek és zárt, szigorían titkos települések Oroszországban" (389. o.) kitétele meglehetősen elgondolkodtató. Szó esik az erősödő és gyengülő nagyvárosi agglomerációkról is, miközben a Szerzők hangsúlyozzák, hogy az orosz agglomerációk száma stabil, ami az ,extenziv agglomeráció-fejlödés” (394. o.) szakaszának lezárulását tükrözi.

A következő tanulmányban Tatyjana Nefjodova az orosz perifériákkal foglalkozik részletes, számos informatív ábrát tartalmazó munkájában. A Szerző a periféria fogalmának több rétegét különbözteti meg (Moszkvától távoli térségek; az egyes régiók peremterületei; a városoktól távoli vidéki körzetek), majd ennek logikája mentén a városi és vidéki térségeken belül is komoly polarizálódást tár fel. Elöbbi kapcsán elemzi a fỏváros nagy és egyre növekvő országos gazdasági súlyát, valamint a regionális jelentőséggel bíró nagyvárosok és a többnyire ezektől távoli kisebb városok markánsan eltérő - a népességszámmal szoros pozitív korrelációt mutató - gazdasági fejlődési kilátásait. Részletesen olvashatunk a vidéki térségek polarizálódásáról is, melynek oka makroszinten az északi és keleti országrészekből a feketeföld övezetbe irányuló tetemes elvándorlás, lokális szinten pedig a városi központtól való távolság jelentőségének felértékelődése. Fontos eredmény továbbá, hogy a vidéki térségeknek nemcsak a közúti elérhetősége kedvezőtlen, de jellemzően az információs hálózatokhoz (pl. internet) sem tudnak csatlakozni; sok község helyzetét mégis valamelyest stabilizálják a városlakók ottani dácsaépítései. A Szerző ezek után a külső és belső perifériák részaránya alapján öt övezetet különböztet meg Oroszországban, melyeket részletesen bemutat. Összefoglaló zárszavában komoly kritikát fogalmaz meg „A falvak szociális fejlesztése 2010-ig” c. szövetségi célprogrammal szemben, mely számos gyengesége (föként markáns mezőgazdasági irányultsága és a területi különbségekre való érzéketlensége) miatt nem kínál hatékony megoldást a tanulmányban bemutatott problémákra. 
A kötetet Szergej Artobolevszkij, Tatyjana Borogyina és Olga Glezer közös elemzése zárja, amely a területi közigazgatási és az önkormányzati rendszer egymáshoz való viszonyát elemzi. A Szerzők rámutatnak a két - a 20. században mindvégig meglehetősen képlékeny - rendszer területi beosztásának jelentős eltéréseire, melyek helyi szinten számos problémát vetnek fel (ilyen például, amikor a helyi önkormányzat nem támaszkodhat a lokális infrastruktúrára, mely az igazgatási egységek határaihoz igazitva épült ki). Részletesen olvashatunk arról is, hogy a közelmúlt változásai sem segítették egyértelmüen a két rendszer közelítését, ami pedig a hatékony regionális politikának alapfeltétele lenne.

Összegzésképpen megállapíthatjuk: a kiadvány sokrétü, alapos és módfelett érdekes munka. A széles témakört felölelö, részletes és naprakész tanulmányok, valamint a megértést segitő táblázatok, diagramok és térképek sokasága tekintélyes, a Szerzök gazdag háttérismeretén és személyes tapasztalatain nyugvó ismeretanyagot közvetít az olvasó felé. A hiánypótló kötetet nagy haszonnal forgathatják mindazok, akik kutatóként, tanárként vagy akár hallgatóként behatóan érdeklődnek Oroszország területi folyamatai iránt. 
Tér és Társadalom 23. évf. 2009/1. 219-238. p.

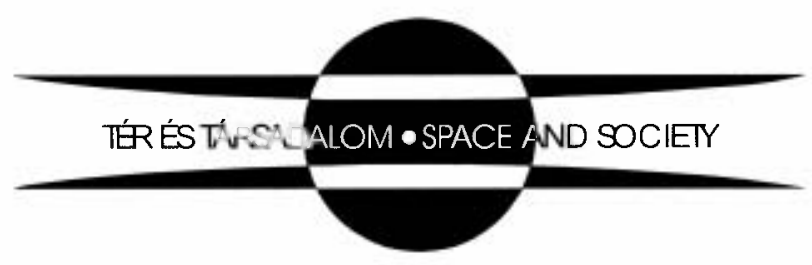

